\title{
Use of Tranexamic Acid in Control of Haemorrhage after Extraction of Teeth in Haemophilia and Christmas Disease
}

\author{
R. W. H. TAVENNER
}

British Medical fournal, 1972, 2, 314-315

\section{Summary}

Bleeding after dental extraction was controlled with tranexamic acid in 19 patients with haemophilia and 3 with Christmas disease. The results were slightly better than those obtained with aminocaproic acid; the dose used was smaller; and side effects were few.

\section{Introduction}

Okamoto and Okamoto (1962) drew attention to tranexamic acid (AMCA) as a more potent inhibitor of the fibrinolytic enzyme system than aminocaproic acid, first introduced by Okamoto (1959). Further research by Melander et al. (1964) and Okamoto et al. (1964) showed that the cyclohexane derivative consisted of two isomers, the more active being the synthetic amino-acid tranexamic acid. This was found by Dubber et al. (1964) to be at least 10 times more potent than aminocaproic acid and the effect to last longer, and Anderson et al. (1965) found it to be seven times more potent. The use of aminocaproic acid in the control of haemorrhage after the extraction of teeth in haemophilia has been investigated by Reid et al. (1964) and Tavenner (1968).

The following is a report of the use of the active isomer of tranexamic acid in the treatment of haemorrhage after the extraction of teeth in 19 cases of haemophilia, three cases of Christmas disease, and one case of von Willebrand's disease at the General Hospital, Birmingham. Up to 1964 some of these patients had extractions when only blood or plasma transfusions were available and these have been.included in the Table for comparison. From 1964 to 1968 aminocaproic acid was used (Tavenner, 1968) and these results have also been included.

\section{Methods}

The operative technique and the local methods for the control of haemorrhage in this series is common to all the cases. None received an initial standard dose of factor VIII. Half an hour before the time of extraction tranexamic acid was given as Cyklokapron in tablet form in a dosage of $1.5 \mathrm{~g}$ every six hours and was continued up to the time that the patient was discharged from hospital. It was maintained at the same dosage throughout the period of treatment in all but two of the cases. In Case 9 the dose was increased to four-hourly because of a spontaneous haemorrhage and in Case 14 it was halved to $0.75 \mathrm{~g}$ and given six-hourly.

The extractions were carried out under local anaesthetic except when infection was present or when the extraction was likely to be difficult. The technique relating to the administration of the anaesthetic and the local treatment of the tooth socket to control the haemorrhage have already been described (Tavenner, 1968).

University of Birmingham Dental School, Birmingham 4 R. W. H. TAVENNER, B.D.S., M.R.C.S., L.R.C.P., L.D.S., Senior Lecturer

\section{Results}

Outbreaks of spontaneous haemorrhage from the tooth socket as a result of the organizing blood clot becoming infected and breaking down again presented a difficulty, as was the case in the series treated with aminocaproic acid. It usually occurred on the third or fourth day, despite the fact that bleeding had been controlled up to then with tranexamic acid. Haemostasis could be obtained only by giving cryoprecipitate, and in the previous series of cases by giving plasma, cryoprecipitate not then being available.

Case 9 had two episodes of spontaneous haemorrhage, one of which continued as a brisk haemorrhage at intervals throughout a 24-hour period, despite the fact that cryoprecipitate was given as soon as the haemorrhage occurred. The periods of cessation of the bleeding did not seem to bear any relation to the administration of the cryoprecipitate. These two episodes of spontaneous haemorrhage necessitated a stay in hospital of a total of 25 days, during which time the patient had 40 packs of cryoprecipitate and 6 litres of blood. Of the three remaining operations on the same patient, one required a stay of eight days and two, both requiring surgical removal of teeth, an average stay of 4.25 days.

Case 8 had two operations which required the removal of impacted lower third molars. After the first operation there was little bleeding from the wound, but on the fourth day there was sudden bleeding into an elbow joint and eight packs of cryoprecipitate were given before discharge on the sixth day. The second operation was followed by very little bleeding and the patient was discharged on the sixth day. He was readmitted after three days following a spontaneous haemorrhage from the wound which had become infected. This haemorrhage was controlled in six days, 16 packs of cryoprecipitate being required in addition to tranexamic acid.

Case $7 \mathrm{had}$ in all nine operations. During the course of one he developed a very painfully swollen hand and was given eight packs of cryoprecipitate and remained in hospital for seven days, three days after the control of haemorrhage from the tooth socket. He had two operations followed by prolonged bleeding, one requiring a stay of eight days, the other a stay of seven days, during which period he received four packs of cryoprecipitate because of discomfort in a knee joint. Of the remaining six operations, the average stay in hospital was 3.5 days, the haemorrhage being controlled with tranexamic acid only.

This difficulty with spontaneous haemorrhage was also observed by Strauss et al. (1965), who showed that the administration of an inhibitor of plasminogen activation did not clinically control or ameliorate spontaneous haemorrhage in patients with severe haemophilia.

Complications such as nausea, vomiting, diarrhoea, and hypotensive attacks were common findings when aminocaproic acid was used. In this series of cases using tranexamic acid, only two patients complained of a mild attack of diarrhoea; in both cases this occurred early in the morning and on only one occasion during their treatment. There were no complications noted in any of the other patients.

The Table of the results is arranged to show the age of the patient at the time of the first extraction, the severity of the haemophilia and Christmas disease in terms of percentage of factor VIII and of factor XI, and the amount of blood, plasma, aminocaproic acid, tranexamic acid, and cryoprecipitate used over all operations in a particular regimen $\mathrm{A}, \mathrm{B}$, or $\mathrm{C}$; also the overall 


\begin{tabular}{|c|c|c|c|c|c|c|c|c|c|c|c|c|c|c|c|}
\hline \multirow{3}{*}{$\begin{array}{l}\text { Case } \\
\text { No. }\end{array}$} & \multirow{3}{*}{$\begin{array}{c}\text { Normal } \\
\text { Clotting } \\
\text { Factor* } \\
(\%)\end{array}$} & \multirow{3}{*}{$\begin{array}{l}\text { Age/Year } \\
\text { at Time } \\
\text { of First } \\
\text { Operation }\end{array}$} & \multicolumn{3}{|c|}{$\mathbf{A}$} & \multicolumn{3}{|c|}{ B } & \multicolumn{4}{|c|}{ C } & \multirow{2}{*}{\multicolumn{3}{|c|}{$\begin{array}{l}\text { Days in Hospital } \\
\text { from Day of } \\
\text { Operation }\end{array}$}} \\
\hline & & & \multicolumn{3}{|c|}{ Using Blood/Plasma Only } & \multicolumn{3}{|c|}{$\begin{array}{l}\text { Using Aminocaproic Acid with } \\
\text { Plasma as Required }\end{array}$} & \multicolumn{4}{|c|}{$\begin{array}{l}\text { Using Tranexamic Acid with } \\
\text { Blood/Cryoprecipitate as Required }\end{array}$} & & & \\
\hline & & & $\begin{array}{l}\text { Litres of } \\
\text { Blood }\end{array}$ & $\begin{array}{c}\text { Litres of } \\
\text { Plasma }\end{array}$ & $\begin{array}{c}\text { No. of } \\
\text { Operations }\end{array}$ & $\begin{array}{l}\text { Amino- } \\
\text { caproic } \\
\text { Acid (g) }\end{array}$ & $\begin{array}{l}\text { Litres } \\
\text { Plasma }\end{array}$ & $\begin{array}{c}\text { No. of } \\
\text { Operations }\end{array}$ & $\begin{array}{c}\text { Tran- } \\
\text { examic } \\
\text { Acid (g) }\end{array}$ & $\begin{array}{l}\text { Litres } \\
\text { Blood }\end{array}$ & $\begin{array}{c}\text { Cryo- } \\
\text { precipitate } \\
\text { Packs }\end{array}$ & $\begin{array}{c}\text { No. of } \\
\text { Operations }\end{array}$ & $\mathbf{A}$ & B & C \\
\hline \multicolumn{16}{|c|}{ Haemophilia } \\
\hline $\begin{array}{r}1 \\
2 \\
3 \\
4 \\
5 \\
6 \\
7 \\
8 \\
9 \\
10 \\
11 \\
12 \\
13 \\
14 \\
15 \\
16 \\
17 \\
18 \\
19\end{array}$ & \begin{tabular}{|c|}
$6 \cdot 4$ \\
2 \\
1 \\
0 \\
3 \\
0 \\
0 \\
0 \\
0 \\
10 \\
1 \\
5 \\
10 \\
$1 \cdot 5$ \\
20 \\
0 \\
0 \\
9 \\
3
\end{tabular} & $\begin{array}{l}15 / 65 \\
31 / 53 \\
17 / 63 \\
29 / 50 \\
34 / 65 \\
16 / 59 \\
41 / 69 \\
22 / 70 \\
31 / 61 \\
14 / 65 \\
24 / 64 \\
30 / 62 \\
19 / 63 \\
9 / 64 \\
27 / 70 \\
24 / 53 \\
27 / 60 \\
19 / 69 \\
24 / 71\end{array}$ & $\begin{array}{l}2 \cdot 23 \\
3 \cdot 9\end{array}$ & $\begin{array}{c}12.5 \\
4.54 \\
\\
7.9 \\
\\
10.5 \\
14.7 \\
13.6 \\
6.8 \\
6.25 \\
4.5 \\
9.6\end{array}$ & $\begin{array}{l}4 \\
1 \\
1 \\
1 \\
2 \\
1 \\
1 \\
2 \\
1 \\
3 \\
1\end{array}$ & $\begin{array}{r}654 \\
116 \\
216 \\
252 \\
324 \\
1,296 \\
252 \\
\\
96 \\
216\end{array}$ & $2 \cdot 84$ & $\begin{array}{l}3 \\
4 \\
1 \\
1 \\
2 \\
4 \\
2 \\
\\
1 \\
1\end{array}$ & $\begin{array}{r}13.5 \\
13.5 \\
16.5 \\
82.5 \\
10.5 \\
36.0 \\
240.0 \\
108.0 \\
283.5 \\
49.5 \\
12.0 \\
9.0 \\
30.0 \\
31.5 \\
18.0 \\
30.0 \\
25.5 \\
63.0 \\
10.5\end{array}$ & 6 & $\begin{array}{l}12 \\
24 \\
40\end{array}$ & $\begin{array}{l}1 \\
1 \\
1 \\
3 \\
1 \\
1 \\
9 \\
2 \\
5 \\
3 \\
1 \\
1 \\
1 \\
3 \\
1 \\
2 \\
1 \\
3 \\
1\end{array}$ & $\begin{array}{r}55 \\
5 \\
11 \\
10 \\
\\
15 \\
11 \\
24 \\
7 \\
13 \\
44 \\
11\end{array}$ & $\begin{array}{r}16 \\
27 \\
5 \\
6 \\
7 \\
32 \\
7 \\
\\
\\
5 \\
5\end{array}$ & $\begin{array}{c}2 \\
2 \\
3 \\
13 \\
2 \\
6 \\
40 \\
18 \\
41 \cdot 5 \\
7 \\
2 \\
2 \\
5 \\
11 \\
3 \\
5 \\
4 \\
10 \cdot 5 \\
2\end{array}$ \\
\hline \multicolumn{16}{|c|}{ Christmas Disease } \\
\hline $\begin{array}{l}20 \\
21 \\
22\end{array}$ & $\begin{array}{l}0 \\
2 \\
0\end{array}$ & $\begin{array}{l}20 / 60 \\
21 / 68 \\
33 / 66\end{array}$ & $1 \cdot 14$ & $23 \cdot 8$ & 5 & $\begin{array}{l}288 \\
324 \\
408\end{array}$ & $\begin{array}{l}1 \cdot 14 \\
9 \cdot 6 \\
4 \cdot 5\end{array}$ & $\begin{array}{l}1 \\
1 \\
2\end{array}$ & $\begin{array}{l}78 \cdot 0 \\
25 \cdot 5 \\
63 \cdot 0\end{array}$ & & & $\begin{array}{l}4 \\
2 \\
4\end{array}$ & 29 & $\begin{array}{r}8 \\
7 \\
11\end{array}$ & $\begin{array}{c}13 \\
4 \\
10 \cdot 5\end{array}$ \\
\hline
\end{tabular}

- Cases 1-19-factor VIII, Cases 20-22-factor IX.

total of the number of days that the patient spent in hospital in relation to each regimen.

Not included in the Table is the case of von Willebrand's disease in a boy aged 13. Two teeth were extracted and he was in hospital for four days and received $12.75 \mathrm{~g}$ of tranexamic acid.

\section{Discussion}

The results of using tranexamic acid in the treatment of haemorrhage from the tooth socket in cases of haemophilia and Christmas disease are very encouraging. Where a comparison can be made it is seen that there is a reduction in the number of days a patient has to spend in hospital when compared with replacement therapy in the form of blood or plasma, although compared with aminocaproic acid this is slight.

The advantages that tranexamic acid have over aminocaproic acid are that it has little if any side effects and the relative smaller dosage required. The average dose of aminocaproic acid given at each operation was $153.04 \mathrm{~g}$ compared with the average dose of $24.5 \mathrm{~g}$ of tranexamic acid given at each operation.

In the 25 operations shown in the Table under A, approximately 8.27 litres of blood and 114.69 litres of plasma were used. The total number of days in hospital amounted to 235, giving an average of 9.4 days for each operation.

In the 25 operations under $B$ when aminocaproic acid was used an overall total of 18.08 litres of plasma was also given. The total number of days spent in hospital was 147 , giving an average of 5.9 days for each operation.

Tranexamic acid was used in 51 operations and the total number of days the patient spent in hospital was 206.5, giving an approximate average of 4 days. One patient required 6 litres of blood and 40 packs of cryoprecipitate and two patients required 12 and 24 packs respectively, giving an overall total of 76 packs.

There is no doubt that fear and anxiety play a very important part with regard to post-extraction haemorrhage and to some extent this was reduced in patients who were given aminocaproic acid, despite its side effects, and even more so when it was necessary for them to have further extractions and tranexamic acid was used. It was MacFarlane and Biggs (1946) who first drew attention to the fact that fibrinolysis could be increased in cases showing fear and anxiety. The fact that the fibrinolytic system may be a factor associated with bleeding in the haemophiliac was pointed out by Astrup et al. (1960).

An accurate assessment is not possible between one patient and another, or indeed in the same patient who has had previous extractions. Where the extraction of a tooth in one patient may be extremely difficult and therefore likely to give rise to more bleeding, the extraction of the equivalent tooth in another patient may be much easier. Likewise, the position in the mouth from which the tooth has to be extracted is important. Less area is exposed in the incisor region than in the molar region from which haemorrhage can occur. Also the fact that patients have their good and bad phases with regard to their haemorrhagic state makes comparison difficult.

It would seem from the results of the above series of cases that tranexamic acid prescribed as Cyklokapron has a very definite part to play in the control of haemorrhage after the extraction of teeth in haemophilia and Christmas disease, but it must be stressed that no teeth should be extracted in these patients except under hospital conditions, and preferably in a hospital which normally treats such patients and where replacement therapy is easily available if it should be required.

I would like to acknowledge the advice given to me by Dr. A. C. Pollock, consultant haematologist at the General Hospital, Birmingham, and the help of Dr. M. B. Fessey, of the haematology department; likewise, the help of Mr. J. Knox, dental registrar, who has been concerned with many of the cases in this series; also, to thank Mr. A. M. Nicholls, of Kabi Pharmaceuticals, who made it possible for the supply of Cyklokapron.

\section{References}

Anderson, L., et al. (1965). Scandinavian fournal of Haematology, 2, 230 Astrup, T., Brakham, P., Ollendorf, P., and Rashmussen, T. (1960). Thrombosis et Diathesis Haemorrhagica, 5, 329.

Dubber, A. H. C., McNicoll, G. P., Douglas, A. S., and Melander, B. (1964). Lancet, 2, 1317.

Macfarlane, R. G and Biggs, R (1946). Lancet, 2,862

Melander, B., Glinielki, G., Granstran, B., and Hanshoff, G. (1964). X Congress of the International Society of Haematology, Abstract G.68. Congress of the International Society of Haema

Okamoto, S. (1959). Keio fournal of Medicine, 8, 211.

Okamoto, S., et al. (1964). X Congress of the International Society of Haematology, Abstract G.65.

Reid, W. U., Lucas, O. N., Francisco, J., Geisler, P. H., and Erslen, A. J. (1964). American fournal of the Medical Sciences, 248, 184

Strauss, H. G., Kew, S. V., and Diamond, L. K. (1965). New England Fournal of Medicine, 273, 303.

Tavenner, R. W. H. (1968). British Dental fournal, 124, 19. 